\title{
A Study on the Role of Web 4.0 and 5.0 in the Sustainable Tourism Ecosystem of Ho Chi Minh City, Vietnam
}

\author{
Nguyen Thien Duy ${ }^{1, *}$, Subhra R. Mondal ${ }^{2, *(\mathbb{D})}$, Nguyen Thi Thanh Van ${ }^{3}$, Pham Tien Dzung ${ }^{4}$, \\ Doan Xuan Huy Minh ${ }^{5}$ and Subhankar Das ${ }^{2, *(D)}$ \\ 1 Administration Office, University of Economics Ho Chi Minh City, Ho Chi Minh City 700000, Vietnam \\ 2 Department of Digital Marketing, Teerthanker Mahaveer University, Moradabad 244001, India \\ 3 Economics Faculty, Ho Chi Minh University of Technology and Education, \\ Ho Chi Minh City 700000, Vietnam; vanntt@hcmute.edu.vn \\ 4 Institute of Development Economics Research, University of Economics Ho Chi Minh City, \\ Ho Chi Minh City 700000, Vietnam; dungpt@ueh.edu.vn \\ 5 Institute for Computational Science and Technology, SBI, Building, Quang Trung Software City, \\ Ho Chi Minh City 700000, Vietnam; minh.dxh@icst.org.vn \\ * Correspondence: thienduy@ueh.edu.vn (N.T.D.); nm120617@gmail.com (S.R.M.); \\ xd5483803@gmail.com (S.D.)
}

Received: 30 July 2020; Accepted: 24 August 2020; Published: 1 September 2020

\begin{abstract}
This research discusses the role of Web 4.0 and 5.0 devices on the commercial sustainability for tourism in Ho Chi Minh City (HCMC), Vietnam. The study adopts a tourist perspective regarding the future implementation of Web 4.0 and 5.0 devices, focusing on the service quality of various tourism-associated services and assessing, in return, the extent to which the overall satisfaction and long-term patronage of tourists is affected. Usually, researchers conduct this test in various popular establishments where devices are intended for experimental use and tourists are supposed to have previous exposure to them, so that their perceptual thinking regarding the service quality of these devices can be studied. The tourists act as respondents for various establishments. We also asked subjective questions in a short interview to 10 professionals working in these establishments, which helped us in the quantitative survey process. As a mixed method study, it has covered both quantitative and qualitative aspects of the items and provided a holistic result. The results indicated that Web 4.0 and 5.0, along with the service quality offered by personnel working in the establishments, showed significant variance in holistic service evaluation for tourist satisfaction and loyalty. Very few service quality factors had a distinct variance in the output. After using a regression analysis for Web 4.0 and 5.0 devices and service quality, we found that Web 4.0 and 5.0 showed insignificant negative results. This study contributes to the incremental research on Web 1.0 to 5.0, specifically detailing how it affects tourists' satisfaction and patronage. Moreover, from a management point of view, this study can help solve the financial riddle of various establishments in HCMCs tourism ecosystem for optimum fund management and better productivity.
\end{abstract}

Keywords: Web 4.0 and 5.0; tourism ecosystem; service quality; tourists' satisfaction and loyalty; Ho Chi Min City; Vietnam

\section{Introduction}

Since the advent of new automated technologies and connectivity innovations, it has become paramount to know the impact of Web 5.0 on sustainable tourism. As suggested by Web 4.0, the interaction between human and machine tourism is likely to be affected. Ever since the symbiotic 
web evolved into the Symbionet decentralized network for Web 5.0, the study of the effect on the tourism ecosystem and sustainable development became a priority. In Web 5.0, tourists try connect via smart communication devices (SC) like smartphones, phablets, and humanoid robots with augmented and virtual reality (AR and VR) in order to enhance their experiences in the three-dimensional (3D) virtual world of Symbionet [1]. This technology uses each part of our memory, along with the power of calculation, for each interconnected SC to provide the virtual world of artificial intelligence (AI). In Web 4.0, the Internet is emotionally unavailable and hardly feels the pulse of user perspectives. However, with Web 5.0, AR- and VR-enabled devices and headgear can enhance user experiences. Experiential marketing is now predominant in the tourism ecosystem to influence the behavioral intention of tourists [2]. Sustainable tourism is undergoing a drastic makeover, with more end-user experience-enhancing technologies in 3D-imprinted virtual reality [3]. Automation and Web 5.0 are important for changing the sustainability of each facet of tourism. Technology advances like 4G and 5G connectivity, big data, Internet of Things (IoT), AR, and VR act as prerequisites for change. Internet of People (IoP) is now incorporating the neural network with AR and VR to enhance real-time experience and give users a 3D feeling [4]. The primary objective of this research was to determine the stakeholders' service quality on tourists' satisfaction and loyalty in the tourism ecosystem, which can be attributed to the incremental changes of Web 5.0.

Web 5.0 affects tourism products, services, hotel industries, profiling of tourists, business models, and various bodies associated with the industry. We conducted interviews using a semi-structured questionnaire on 812 participants. As a preliminary support to our quantitative survey, we asked about respondents' devices and their awareness of the Vietnamese hotel staff, travel agents, managers of private establishments and tourism administrators who play a supporting role in providing a better qualitative service to the tourists. They were also asked questions about operational know-how, satisfaction, and loyalty aspects regarding these devices, and what they think the impact is of these devices and their deployment.

The results showed that the majority of stakeholders are aware of Web 5.0 and its impacts as a constituent of overall service quality that holistically affects the satisfaction of tourists and the futuristic outlook of service establishments. The stakeholders also believe that Web 5.0 will bring new business models to a technology-driven era, with producers futuristic in their viewpoint. Younger tourists are more dependent on AR and VR with $4 \mathrm{G}$ and $5 \mathrm{G}$ when choosing between different tourist packages. Sustainable tourism exists where there is long-term tourist patronage and loyalty is reflected in all the endorsements of the various services offered.

In this study, researchers try to judge the holistic effect of Web 5.0 integration into various forms of tourism and related services in Ho Chi Minh City (HCMC), Vietnam, for appraising the satisfaction and loyalty of tourists. This integration can result in the long-term potential of sustainable smart tourism for the city, which greatly contributes to the gross domestic product (GDP) of the country.

Service quality is a necessary antecedent of tourist satisfaction and long-term patronage that results in loyalty in tourism marketing literature. It is the most challenging concept to actualize, as it considers the value proposition of the tangibility-intangibility complements of service [5]. With the rapid introduction of new communication technologies, the service sector is evolving quickly, with digitalization acting as a catalyst and artificial intelligence (AI) supporting the framework of new tourism innovations. To reach a more substantial mass and establish the operational superiority of tourist engagement, web technologies are becoming a pivotal force [6-8].

\subsection{Evolution of Web in Tourism}

In 1990, the internet was the main tool for creating online static brochures. It is known as Web 1.0.

In 2005, Web 2.0-Here social networking websites, blogs, and podcasts became popular. Tourists use these mediums to share their experience with others about service providers. Audio, video, and text messages became the tools through which tourists communicated more [9]. So, the human interaction became very dominant force. 
In 2007, Web 3.0-Semantic Web searches focused on context analysis and word meanings. It collaborated with various other sectors to accumulate information in e-commerce and e-health, as well as for use in the tourism sector. Here, information was be semantically attached to a corresponding level of relevance for a better output. Metadata (i.e., data of existing information) were cultivated for more remarkable results. Moreover, Web 3.0-Network Digital technology along with human cooperation focused on the transition from information orientation to knowledge orientation. It connected human cooperation with machines' digital ability and came out as digitalized organic source knowledge. It made interaction on the internet more fruitful and searching became a chutzpadik, self-collected, confident shareable, and informative experience [10]. It connected to what one can do with available information and gave a structural meaning to data. It was not an upgrade type of software. Instead, it was an evolution of web interference in tourism. It extended to Web 4.0 and 5.0, which represented web integration and decentralized smart communication [11].

In 2010, Web 4.0 AI agents acted as middlemen of human and machine interaction, dealing with the basic notion of computers and working without programs or apps. Web 4.0 had herculean potential in the tourism and hospitality industry. Web 4.0 also mostly worked on AI.

In 2017, Web 5.0 became a decentralized idea based on the Symbionet web. Here, a personal server (PS) was not always possible and people could be interconnected by a smart connector for communication like virtual reality devices and augmented reality tools (smart glasses). The Symbionet could be a part of emotional and cognitive elements in tourists. The Web can no longer be neutral. Companies like Emotive systems have built smart headphones by which one can connect with real-time facial expression and change output simultaneously [11]. Web 5.0 virtual reality brings emotional and cognitive impedance.

Therefore, in this incremental development of tourism services, these -based Web 4.0 and virtual reality backed Web 5.0 aim to enhance and augment the service for tourists. They are used to generate positive experience in tourists' minds (satisfaction) and long-term patronage (loyalty). Tourism always depends on tourists and their views. This reflective index of satisfaction and loyalty are the true reflection of service quality. All available research has mostly targeted Web 4.0 or AI-based tools for their service quality for tourists' perceptual evaluation. Still, we tried to integrate Web 4.0 and 5.0 to enhance service quality based on positive experiences and long-term patronage. Therefore, we herein attempted to fulfill the gap of Web 5.0 in service quality studies.

Technology always supports human intelligence and does not replace labor. However, with rapid technological advancement, it is practical to think that artificial intelligence may replace human intelligence. Similarly, Web 5.0 applications like AR and VR technologies are mostly futuristic. They are touted to help tourism service along with AI and other Web 4.0 applications to be the next revolution in this industry. Various blogs and articles support the tourism services in the future [12-16]. $\mathrm{AR}$ and VR also impact destination tourism by enhancing the reputation of the place and create an image of multisensory, picturesque, and conscious perceptual representations of a city or country for all inbound tourists [17-21].

Web 4.0 and 5.0 can only enhance technological support to replace certain activities, not jobs [22,23]. Here, we provide a detailed review along with insights into Web 4.0 and 5.0 applications in tourism services that can not only impact employee productivity but total productivity [23]. These devices undoubtedly affect employees' perceptual thinking, attitude, and behavior, as they believe that these devices could replace them in the near future [22]. Tourist engagement along with consumption of service consists of service personals and tangible elements. As there is a gap in tourists' responses to Web 4.0 and 5.0 devices, we tried to study tourist satisfaction and loyalty for these devices in the implemented destinations. The tourism ecosystem includes transportation, hospitality, wellness, and other related services. In Ho Chi Minh City (HCMC), air travel, surface transportation, hotel, restaurants, coffee houses, pubs, attractive places, and spas all contribute to a holistic perceptions of the city's ecosystem. For this study, we selected 812 tourists in HCMC with experience using Web 4.0 and 5.0 devices. We thus tried to explore tourists' previous experience with these tools in 
various hospitality fields like hotels, spa, bars, and restaurants. HCMC is the biggest commercial hub in Vietnam. Vietnam attracted nearly 18 million tourists in 2019, 60\% of whom were Asian (i.e., Chinese and South Koreans), 24\% Europe (French and English), 9\% American, and 6\% Afro-Oceanian [24,25]. Since 2014, Hanoi, Hoi An, and HCMC have been placed in TripAdvisor's top 25 tourist destination list, probably because of its scenic natural beauty, beaches, and opportunity to explore military tourism (i.e., to see archives of history related to Vietnam's war) [26]. HCMC and Vietnam are prominent in deploying new technologies. Since Vietnam is having a rich tourism ecosystem with great hospitality, we selected prominent hotels, spas, restaurants, and bars to use these devices, as these establishments can afford to spend money.

In the recent past, tourism institutions found that the intention to use Web 4.0 and 5.0 devices is always present. Tourists think that these devices can help improve operational efficiency, but simultaneously tourists want human elements to remain [27]. Tourists love to interact with other humans; they think that machines can give more efficient service, but the humanistic touch provides them with a sense of organic happiness [23]. Therefore, somewhere there is a systematic gap between what tourists need and what they can be provided with [28]. Very few research has examined the tourist perspective [8]. Thus, we tried to explain how the gap can be filled by studying the way tourists reciprocate to various services offered by Web 4.0 and 5.0 devices.

Because these devices vary from chatbots to VR/AR, we concentrated on social robots, AR devices, VR spectacles, and chatbots prominent in the tourism ecosystem. This research targeted tourists with previous experience and exposure to these devices while exploring various tourism destinations, so to have a realistic output for the whole HCMC ecosystem and, if possible, Vietnam. We standardized the service aspect to how they are used or how tourists want them to be used for maximum personalized and custom-made services. Social robots are aimed at giving more customized and standardized service when required. Chatbots give digital assistance to physical employees when serving tourists. IVRS helps tourists order services. With VR and AR, the virtual augmented experience can give tourists much needed anxiety and curiosity to explore different services before actually booking them. Thus, these benefits can lift the existing tourism ecosystem and improve tourist satisfaction and loyalty.

\subsection{Literature Review}

Web 4.0 is defined as the machine learning intelligence for robots and chatbots deployed commercially for operational efficiency $[29,30]$. These devices are programmed to act like human intelligence and perform cognitive and emotive activities. Apple's AI applications, i.e., "Siri", is already familiar to many consumers as an integrated voice-enabled assistance tool. Therefore, conceptualization and operationalization are important for AI-powered devices. The nature of these devices is innate and programmed individually. They are represented as humanoid and related devices or applications. These devices bring significant value to those curious or knowledgeable about such devices. They are programmed to perform economic activities along with regular order-based tasks. They facilitate employees in their businesses for superior efficiency and uniqueness, and have better-customized outputs and increased job efficiency [31-33]. AI-enabled devices are primarily deployed in hotels, spas, bars, and pubs for operational efficacy and to accommodate queries [34]. AI-induced devices have also been deployed into other services [35]. In Perm, Russia, an AI influenced female look-alike robot served as a clerk in public government office [36]. Spot and pepper devices play cheerleaders in empty stadiums for baseball matches in Japan [37]. Robots and AI devices are planned to replace the aging workforce in Japan [38]. A six-foot tall humanoid, Cobo, is a bartender making cocktails in Seoul [39]. These updated deployments of AI induced robots have created a significant uproar of further use in all aspects of tourism services [40]. Tourist engagement is not limited to greeting devices or helping apps, nor planning assistants or directional guides. Rather, they are interactive and more than what tourists expect. As such, Vietnam wants to develop the gross safety and value addition in the existing tourism ecosystem. Web 4.0 and 5.0 devices provide digital expertise to all tourists depending on location and commercial benefit [41]. 
For Web 5.0 devices, we explored every prominent and available device to signify the service quality and its effect on tourist satisfaction along with loyalty. Tourists try to use the device to get a virtual experience called a "Phygital experience", where the destination and services associated with an ecosystem continuously evolve, which helps virtually represent physicality [42]. This enhances the image of tourism as an aesthetic satisfaction. Web 5.0, enhanced by virtual reality, provides for extensive consumption. The feeling of a virtual environment offers enjoyment and efficiency in destination marketing [43]. The mode of communication provides prominent information about a destination for tourists. They can get more satisfaction by engaging with something new [44]. VR holds a plethora of opportunities for tourism [45]. VR has many tools to boost tourism, i.e., physically they can use a device and virtually have an experience. This dual phenomenon demands attention. The proper planning and management of the entertainment quotient gives a massive boost to heritage tourism [46]. In HCMC, there is the opportunity to utilized VR in military and heritage tourism experiences. Tourists can be shown these things virtually to have the experience of imperial and military history. VR can also help preserve Vietnam's rich flora and fauna. Therefore, virtual and augmented reality is an important development for tourism despite its technical challenges and opportunities.

\section{Theoretical Background and Hypothesis Development}

\subsection{Web 4.0 and 5.0 Devices and Service Quality}

Because Web 4.0 and 5.0 devices commercially develop service quality for various constituents in a tourist ecosystem, they can be considered as an element of service quality for hotels, spas, restaurants, etc. Service quality is regarded as an antecedent of long-term loyalty and satisfaction [5]. Until now, no research has included Web 5.0 (VR/AR) in service quality and its effect on long-term patronage and positive satisfaction. Although some research on hotels and restaurants include social robots and chatbots, not all VR devices are in this same bracket of service quality. Since these have technical implications, prior investigations have indicated the importance of possessing expertise regarding Web 4.0 devices. Still, no study has focused on Web 5.0 devices, which can induce tech-based satisfaction and loyalty for tourists. By employing a critical incident method, we observed that self-service has its own positive and negative experiences for tourist engagements [47]. For tourists, self-service generates satisfaction, comfort of use, and punctuality. Yet, above all, it is better than service employees. When technology fails to give instant results, tourists feel bad too. Customer relation management (CRM) is helpful in addressing technology-driven dissatisfaction, as it directly affects the tourists' satisfaction and loyalty [48]. CRM attracts a substantial financial investment. If this can successfully address the concerns of tourists, then it may generate more immediate satisfaction [49]. This techno-service quality has four determinants like prompt tourist service, secure technology for quality information, the comfort of using technology, and trustworthiness of service output. Two factors out of these four are significantly related with tourist satisfaction and loyalty. Thus, we concluded the following hypotheses:

Hypothesis 1 (H1). Web 4.0 and 5.0 service quality devices have a positive association with tourist satisfaction.

Hypothesis 2 (H2). Tourist satisfaction with Web 4.0 and 5.0 service quality devices positively relate to tourist loyalty.

\subsection{Physical Employee Service Quality and Tourist-Oriented Outputs}

The tangibility and intangibility trade-off is integral to service quality [5]. Tangibility is represented by various servicescapes like equipment, tools, and physicality. The intangibility aspect is represented by responsiveness, reliability, trustworthy assurance, and empathetic behavior [50]. Tangible elements are involved with tourist-driven organizations like restaurants, hotels, pubs, etc. They affect the service quality as tourists recognize the differentiation of these services. The line employees are the 
first point of contact. Therefore, the intangible image of an organization depends on the first point of contact and their behavior is pivotal for service quality perception [51,52]. The popular SERVQUAL model represents reliability, empathy, assurance, responsiveness, and tangibility. The first four factors represent prompt service, accurate and consistent caring, and employee relations. Tangibility factors show the service area and physical appearance of employees. For Web 5.0, employees' behavior and performance are paramount. The perceptual image of employees helps recall an image of the destination by using virtual reality devices [19]. Therefore, the web-based destination image of the tourism ecosystem is crucial for creating a virtual image via a tangible VR or AR tool [53]. The mental image of a place or organization impacts the total tourism ecosystem of a situation [54]. Web 5.0 can help develop virtual reality tourism in a tourism ecosystem $[55,56]$. Thus, we concluded the following hypotheses:

Hypothesis 3 (H3). Physical employee service quality is positively related to tourist satisfaction.

Hypothesis 4 (H4). Tourist satisfaction with physical employees is positively associated with tourist loyalty.

Web 4.0 and 5.0 devices not only provide comfort for tourists but they also affect service engagement $[6-8,57]$. A microscopic investigation was carried out for tourist service responses rendered by Web 4.0 and 5.0 compared to physical employee service. When tourists were dissatisfied with Web 4.0 and 5.0 devices, they sought out physical employees [58,59]. Thus, we concluded the following hypotheses:

Hypothesis 5 (H5). Physical employee service quality shows more variance in holistic service quality than Web 4.0 and 5.0 service quality.

Hypothesis 6 (H6). Physical employee service quality shows more variance in holistic tourist loyalty than Web 4.0 and 5.0 service quality.

\section{Research Methodology}

\subsection{Research Samples}

The authors conduct this research in prominent hotels, spas, restaurants, and pubs where these devices were planned for future. Only tourists with previous experience using devices were encouraged to respond. Tools like social robots, chatbots, digital voice assistance, and VR/AR goggles were standardized.

\subsection{Research Instrument}

Web 4.0 and 5.0 devices vary across the platform of service. Here, we adopted a service quality approach for the devices defined across different blogs [60], which reflects hotel service for tourists with some kind of previous exposure. Device pictures were shown to them and functionality was explained. Mostly, the instrument was prepared in English; we targeted English-speaking tourists. For content validity, we carried out the survey at establishments with preliminary exposure to Web 4.0 and 5.0 devices or establishments who planned to use these devices in the future. We also solicited the opinion of senior managers with more than 10-12 years of experience to validate 15 items in which participants were encouraged to rate service quality on a Likert scale $(1=$ strongly disagree and $5=$ strongly agree). The core items of the questionnaire are detailed in Table A1.

Besides tangibility, we considered the SERVQUAL model's four dimensions for physical employee services. Six items were used for responsiveness, with a Cronbach's alpha of 0.89 . Five things were deployed to assess the reliability of service with an alpha value of 0.78 . Eight items represented an assurance of service with an alpha value of 0.89 . Five items stood for the empathetic service of 
an employee with a Cronbach's alpha of 0.82 . One item represented tourists' overall perception of service quality.

Tourist satisfaction with the service quality of Web 4.0 and 5.0 devices was measured by three items $[61,62]$ that represented overall satisfaction and physical employee services (the Cronbach's alpha was 0.79 and 0.81 , respectively). Tourist loyalty was measured by items such as if they gave referrals, reviewed positive electronic word of mouth (e-WOM) on various platforms, or were willing to pay a premium price for these services [63]. Here, the alpha value was 0.86 , with responses recorded on a Likert scale $(1=$ strongly disagree and $5=$ strongly agree).

We also collected 10 responses from the staffs at hotels, spas, bars, and travel establishments who deployed devices to have a distinctive technical value added to their services. We selected such establishments with good reputations and popularity among English-speaking tourists. The short interview schedule featured five subjective questions regarding awareness and technical know-how for Web 4.0 and 5.0 devices. Apart from these five questions, we also asked what they thought of devices and how they perceived their impact on service. We prepared the questions in English and field data collectors explained them to participants in Vietnamese after responses were collected. After, they were again translated to English from Vietnamese. Participants were selected based on their experience ( 8 to 12 years of active engagement) in the sector and knowledge of new developments.

\subsection{Data Collection}

After consulting with the managers of various tourist establishments, we finalized the dimensionality for the devices. The survey questionnaire was prepared in such a way that face validity was confirmed and responses were recorded in 10-15 min. As such, respondents' fatigue was prevented [64]. Yet there were some gaps for when we selected 812 samples from 834 returned responses. A pilot test also confirmed minor modifications to the items with 30 randomly collected responses. Field survey assistants received responses from tourists with prior permission from the establishments, who encouraged them answer with a free mind. They even provided tourists with candies as a token of appreciation. Moreover, some responses were collected via social platforms like Facebook groups and Zalo, where the questionnaire was administered via the Survey Monkey website as an economical method of collecting responses [65].

We tried to minimize the common method bias for the survey by selecting Tabachnick's pre-tested format [66]. Questions did not have any ambiguity. Respondents were informed at the beginning of the survey that their responses would be used for academic research and no business propositions would be made. They were free to answer how they chose.

\subsection{Descriptive Statistics}

Table 1 shows responses from 812 tourists, where the total number of responses by demographic representation can be seen. The study consisted of 508 males and 304 females. Age classifications were distributed over six segments. The education level of tourists was divided into four categories. Annual income in US dollars was split into six segments. Employment level of tourists was split into five segments. Marital status was split into three segments.

For the 10 professionals, we asked five questions about Web 4.0 and 5.0 devices regarding what they know about devices like social robots, digitalized chatbots, IVRS supported by robots, VR appliances, and automated data processing using AR tools. Their responses are shown in Table 2. The first question we asked was what they knew about devices; pictures were shown to them. Second, we asked how they thought devices would impact the operation of tourism services. Third, we asked what were factors of good service and how they impacted working culture. Fourth, we asked how these devices affected the overall satisfaction in comparison to physical service. Fifth, we asked how they assessed loyalty for these devices compared to physical service. 
Table 1. Descriptive statistics of tourists'.

\begin{tabular}{|c|c|c|}
\hline Item Definition & Frequency & Percentage \\
\hline \multicolumn{3}{|c|}{ Gender } \\
\hline Male & 508 & $62.56 \%$ \\
\hline Female & 304 & $37.43 \%$ \\
\hline \multicolumn{3}{|c|}{ Age } \\
\hline 20-29 years & 44 & $5.41 \%$ \\
\hline 30-39 years & 436 & $53.69 \%$ \\
\hline 40-49 years & 146 & $17.98 \%$ \\
\hline 50-59 years & 123 & $15.14 \%$ \\
\hline $60-69$ years & 39 & $4.80 \%$ \\
\hline 70-79 years & 24 & $2.95 \%$ \\
\hline \multicolumn{3}{|c|}{ Education } \\
\hline Secondary school & 65 & $8.00 \%$ \\
\hline Graduate & 462 & $56.89 \%$ \\
\hline Masters & 131 & $16.13 \%$ \\
\hline More than Masters & 154 & $18.96 \%$ \\
\hline \multicolumn{3}{|c|}{ Annual Income } \\
\hline Less than $\$ 20,000$ & 37 & $4.55 \%$ \\
\hline$\$ 20,000-\$ 39,999$ & 440 & $54.18 \%$ \\
\hline$\$ 40,000-\$ 59,999$ & 153 & $18.84 \%$ \\
\hline$\$ 60,000-\$ 79,999$ & 130 & $16.00 \%$ \\
\hline$\$ 80,000-\$ 99,999$ & 39 & $4.80 \%$ \\
\hline More than $\$ 100,000$ & 13 & $1.60 \%$ \\
\hline \multicolumn{3}{|c|}{ Employment Position } \\
\hline Student & 27 & $3.32 \%$ \\
\hline Unemployed & 38 & $4.67 \%$ \\
\hline Employed & 425 & $52.33 \%$ \\
\hline Self-employed & 293 & $36.08 \%$ \\
\hline Retired & 29 & $3.57 \%$ \\
\hline \multicolumn{3}{|c|}{ Marital Status } \\
\hline Single & 107 & $13.17 \%$ \\
\hline Married with children & 228 & $28.07 \%$ \\
\hline Married without children & 477 & $55.04 \%$ \\
\hline
\end{tabular}

Table 2. Descriptive representations of 10 professionals and their opinions.

\begin{tabular}{lllll}
\hline $\begin{array}{l}\text { Respondents } \\
\text { (Professional/Employee) }\end{array}$ & Gender & $\begin{array}{l}\text { Age } \\
\text { (years) }\end{array}$ & $\begin{array}{l}\text { Experience in } \\
\text { Industry (years) }\end{array}$ & Opinion about Devices \\
\hline 1 & Male & 34 & 10 & $\begin{array}{l}\text { Knew about devices, i.e., robots, chatbots, interactive } \\
\text { voice response system (IVRS), support, and VR. } \\
\text { Less aware of AR devices. Had concern about what } \\
\text { would happen to physical service when these } \\
\text { devices like this were employed }\end{array}$ \\
\hline 2 & Female & 35 & 11 & $\begin{array}{l}\text { Had a great awareness about the devices and was } \\
\text { excited about how they would be deployed. }\end{array}$ \\
\hline 3 & Male & 42 & 12 & $\begin{array}{l}\text { Knew about devices and their prospective use. Had } \\
\text { concern about future job prospects if devices took } \\
\text { over jobs. }\end{array}$ \\
\hline 4 & Male & 36 & 10 & $\begin{array}{l}\text { Had a strong awareness of the devices. Was happy } \\
\text { to work with and use the devices. }\end{array}$ \\
\hline 5 & Female & 32 & 9 & $\begin{array}{l}\text { Had an awareness of the devices. Was happy to with } \\
\text { new changes; felt she could develop expertise. }\end{array}$ \\
\hline
\end{tabular}


Table 2. Cont.

\begin{tabular}{|c|c|c|c|c|}
\hline $\begin{array}{l}\text { Respondents } \\
\text { (Professional/Employee) }\end{array}$ & Gender & $\begin{array}{l}\text { Age } \\
\text { (years) }\end{array}$ & $\begin{array}{l}\text { Experience in } \\
\text { Industry (years) }\end{array}$ & Opinion about Devices \\
\hline 6 & Female & 35 & 10 & $\begin{array}{l}\text { Knew about all devices except VR and AR. } \\
\text { Apprehensive about their application and how } \\
\text { effective they would be when serving tourists. }\end{array}$ \\
\hline 7 & Female & 33 & 8 & $\begin{array}{l}\text { Knew about all devices except AR. Was recently } \\
\text { introduced to VR devices. Was confident that } \\
\text { devices added value to tourist satisfaction; was } \\
\text { doubtful about how devices would aid loyalty. Was } \\
\text { sure that with repeated exposure employees could } \\
\text { handle devices better. }\end{array}$ \\
\hline 8 & Male & 39 & 10 & $\begin{array}{l}\text { Knew about robots and their usage. Had concern of } \\
\text { future employability and posited that one day } \\
\text { machines would replace human beings in every } \\
\text { aspect. Was sure that tourists were satisfied with the } \\
\text { devices. Thought that the human touch was } \\
\text { necessary for establishing loyalty. }\end{array}$ \\
\hline 9 & Male & 41 & 11 & $\begin{array}{l}\text { Had clarity on all devices. Had doubt on how to } \\
\text { operate devices but wanted to learn. Emphasized } \\
\text { that loyalty was only possible via the human element. } \\
\text { Suggested empathy can only help generate loyalty. }\end{array}$ \\
\hline 10 & Female & 37 & 10 & $\begin{array}{l}\text { Knew all devices and their operation. Was sure that } \\
\text { satisfaction was connected to standardized service; } \\
\text { had apprehensions about loyalty. Emphasized that } \\
\text { without the human touch, satisfaction and loyalty } \\
\text { would be difficult to achieve. }\end{array}$ \\
\hline
\end{tabular}

\section{Analysis of Data}

When judging the factorial validity of Web 4.0 and 5.0 device service quality scales, we randomly segregated samples (no distinct difference in t-tests and Chi-square tests) into two parts for exploratory factor analysis (EFA) and confirmatory factor analysis (CFA) [67]. After applying EFA to the first division of samples, we found a five-factorial framework $\left(\chi^{2}=56.57\right.$; degree of freedom $=40 ; \mathrm{CFI}=0.99$; $\mathrm{TLI}=0.98$; RMSEA $=0.05$ ). Therefore, the items of the reciprocating dimension reliably loaded after conducting CFA on the second set of samples, which undermined the goodness of fit in the EFA structure. The results were as follows: $\chi^{2}=537.14$; degree of freedom $=80 ; \mathrm{CFI}=0.95 ; \mathrm{TLI}=0.95$; RMSEA $=0.09$. The items reasonably accepted factor loading for each factor with an excellent composite reliability (CR) and average variance extracted (AVE) (Table 3). This showed a good, acceptable convergent validity $(\mathrm{CV})$ and the square root of AVE was more than inter-factorial correlation, which suggested good discriminant validity (DV).

For investigating Web 4.0 and 5.0 devices and physical employee services impact on tourist satisfaction and loyalty, two factors were considered as second-order factors for knowing the holistic impact. They were treated as a first-order factor to judge the effect of each element on the outcome. The sub-dimensional items underwent first-order factors to deduce the overall holistic effect. The second-order CFA goodness of model fit index for both Web 4.0 and 5.0 devices and physical employee service was found to be acceptable, as shown in Table 4 . The path coefficients and first-order factor structure were significant at a 0.05 level of significance. Moreover the goodness of fit for the second-order dimension model after a one factor CFA averaged the was also found to be acceptable [68]. This showed that the second-order factor model for two constructs was acceptable for consequent correlation testing, as represented by Table 5 . 
Table 3. Factor loading for Web 4.0 and 5.0 service quality devices.

\begin{tabular}{|c|c|c|c|c|c|c|}
\hline Devices and Corresponding Items & Mean & Standard Deviation & FL & Alpha & CR & AVE \\
\hline Social Robots & & & & 0.83 & 0.84 & 0.71 \\
\hline Suggesting sightseeing & 6.16 & 1.81 & 0.81 & & & \\
\hline Promptly responding to queries & 6.12 & 1.75 & 0.84 & & & \\
\hline Games and tourist engagement & 6.68 & 1.78 & 0.85 & & & \\
\hline Digitalized support by Chatbots & & & & 0.86 & 0.88 & 0.65 \\
\hline Prompt access to service & 6.12 & 1.58 & 0.84 & & & \\
\hline Quick online support & 6.24 & 1.68 & 0.85 & & & \\
\hline Itinerary scheduling & 6.45 & 1.78 & 0.74 & & & \\
\hline IVRS support by Robots & & & & 0.84 & 0.86 & 0.61 \\
\hline Food ordering & 6.65 & 1.67 & 0.89 & & & \\
\hline Advice for special menus & 6.77 & 1.69 & 0.91 & & & \\
\hline $\begin{array}{l}\text { Assisting in regulating temperature and } \\
\text { room lighting }\end{array}$ & 6.65 & 1.68 & 0.92 & & & \\
\hline $\begin{array}{c}\text { VR travel and sightseeing experience } \\
\text { enhancement }\end{array}$ & & & & 0.86 & 0.88 & 0.64 \\
\hline $\begin{array}{l}\text { Convenient to see and be familiar with } \\
\text { attractive places and their know-how }\end{array}$ & 6.61 & 1.65 & 0.68 & & & \\
\hline Offers for promotion by VR & 6.17 & 1.71 & 0.73 & & & \\
\hline $\begin{array}{l}\text { VR experience for booking and experiencing } \\
\text { routes }\end{array}$ & 6.38 & 1.52 & 0.77 & & & \\
\hline Auto Data management; Robots with AR. & & & & 0.82 & 0.83 & 0.61 \\
\hline Customized offers & 6.15 & 1.67 & 0.81 & & & \\
\hline $\begin{array}{l}\text { Remember the tourists' preference and } \\
\text { website browsing history for the same }\end{array}$ & 6.12 & 1.59 & 0.78 & & & \\
\hline Return journey assistance & 6.31 & 1.68 & 0.76 & & & \\
\hline
\end{tabular}

Table 4. CFA model that assessed second-order constructs.

\begin{tabular}{ccc}
\hline Tests & $\begin{array}{c}\text { Web } \mathbf{4 . 0} \text { and } \mathbf{5 . 0} \text { Device Service } \\
\text { Quality }\end{array}$ & Physical Employee Service Quality \\
\hline Second-order CFA Chi-square & $\chi^{2}=340.4$ d.f. $=91$ & $\chi^{2}=1360.6$, d.f. $=276$ \\
CFI & 0.95 & 0.94 \\
TLI & 0.92 & 0.91 \\
RMSEA & 0.07 & 0.05 \\
One-factor CFA Chi-square & $\chi^{2}=33.94$, d.f. $=5$ & $\chi^{2}=27.75$, d.f. $=2$ \\
CFI & 0.99 & 0.98 \\
TLI & 0.97 & 0.97 \\
RMSEA & 0.08 & 0.05 \\
\hline
\end{tabular}

Table 5. Correlations and square root of AVE for dimensions.

\begin{tabular}{ccccccc}
\hline Dimensions & $\mathbf{1}$ & $\mathbf{2}$ & $\mathbf{3}$ & $\mathbf{4}$ & $\mathbf{5}$ & $\mathbf{6}$ \\
\hline Web_Device_Serv_Quality & 0.79 & & & & & \\
Tourist_Sat_Web_Device & $0.38^{* *}$ & 0.82 & & & & \\
Physical_Empl_Serv_Quality & $0.58^{* *}$ & $0.34^{* *}$ & 0.94 & & & \\
Tour_Sat_Phy_Empl_Serv_Quality & $0.31^{* *}$ & 0.04 & $0.46^{* *}$ & 0.81 & & \\
Service quality & $0.39^{* *}$ & $0.29^{* *}$ & $0.79^{* *}$ & $0.36^{* *}$ & & \\
Tourist loyalty & $0.26^{* *}$ & $0.26^{* *}$ & $0.48^{* *}$ & $0.33^{* *}$ & $0.47^{* *}$ & 0.78 \\
\hline & ${ }^{* *} p<0.01$. & & & &
\end{tabular}

\subsection{Hypothesis Testing for the Factors}

Before testing our hypotheses, we evaluated how web devices and physical employee service quality were reciprocated in overall service quality. Web devices were found to contribute $20 \%$ to overall service quality, whereas physical employee service contributed $65 \%$ to overall service quality. Therefore, physical employee service was evident. Table 3 shows that the digitalized support from chatbots and robot- and AR-induced auto data management had almost no effect on web device service quality. On the other hand, the responsiveness of physical employees did not impact total service quality. While applying the regression on all web devices and physical employee service quality, 
we observed that the web device and their service quality negatively affected overall service quality. In contrast, physical employees and their service quality was found to be positive.

Results of hypotheses 1 and 2 showed that Web 4.0 and 5.0 device service quality had a positive effect on tourist satisfaction ( $B=0.41$ at $p<0.001$ ), which influenced tourist loyalty $(B=0.25$ at $p<0.001$ ) at a $95 \%$ confidence interval. Web 4.0 and 5.0 device service quality also had a direct effect $(\beta=0.26)$ and an indirect effect $(B=0.16)$ at $p<0.001$ on tourist loyalty, as represented in Figure 1 .

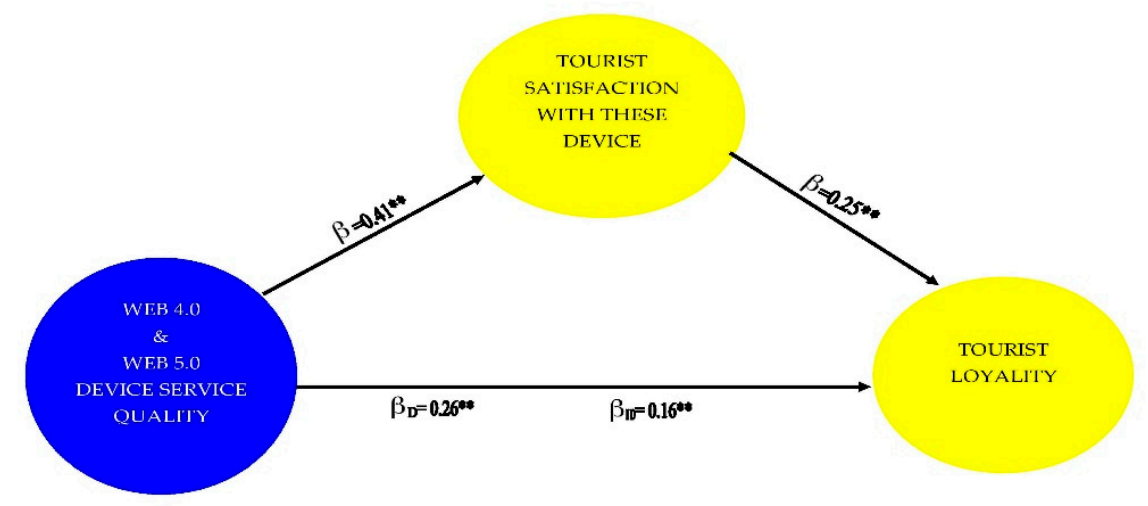

Figure 1. Relationship between Web 4.0 and 5.0 device service quality with tourist satisfaction and loyalty at $p<0.001$.

Similarly, with regard to physical employee service quality, we observed that it positively impacted tourist satisfaction $(\beta=0.38)$. It also affected tourist loyalty $(B=0.28)$ at $p<0.001$ and a $95 \%$ confidence interval. Physical employee service quality also had a direct effect $(\beta=0.48)$ and an indirect effect $(B=0.39)$ at $p<0.001$ on tourist loyalty, as shown in Figure 2.

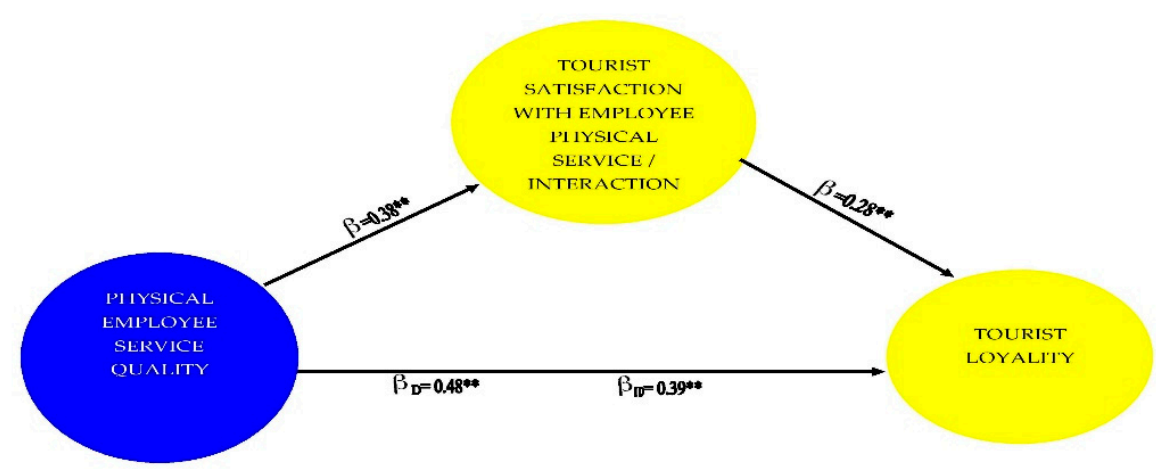

Figure 2. Relationship between physical employee service quality, tourist satisfaction, and loyalty at $p<0.001$.

Since a confidence interval of $95 \%$ did not overlap with these relations, we can safely state that tourist satisfaction and physical employee service quality have a stronger effect on tourist loyalty than Web 4.0 and 5.0 devices.

With further analysis of web device service quality, physical employee service quality, and their respective effect on tourist satisfaction and loyalty, we observed that social robots have a strong influence on overall service quality and reliability, as well as a substantial impact on tourist satisfaction. However, no physical employee service quality dimensions were significant for tourist loyalty, as shown in Table 6. 
Table 6. Effect of relative dimensions on tourist-related outcomes.

\begin{tabular}{|c|c|c|c|c|c|c|c|}
\hline $\begin{array}{l}\text { Web } 4.0 \text { and } 5.0 \text { Device } \\
\text { Service Quality }\end{array}$ & $\begin{array}{l}\text { Service } \\
\text { Quality }\end{array}$ & $\begin{array}{l}\text { Tourist_Sat_ } \\
\text { Web_Device }\end{array}$ & $\begin{array}{l}\text { Tourist } \\
\text { Loyalty }\end{array}$ & $\begin{array}{c}\text { Physical Employee } \\
\text { Service Quality }\end{array}$ & $\begin{array}{l}\text { Service } \\
\text { Quality }\end{array}$ & $\begin{array}{l}\text { Tour_Sat_Phy_ } \\
\text { Empl_Serv_Quality }\end{array}$ & $\begin{array}{l}\text { Tourist } \\
\text { Loyalty }\end{array}$ \\
\hline Social Robots & $0.17^{*}$ & $0.26^{* * *}$ & $0.18^{*}$ & Responsiveness & -0.04 & -0.01 & 0.08 \\
\hline $\begin{array}{l}\text { Digitalized support by } \\
\text { Chatbots }\end{array}$ & -0.08 & 0.07 & -0.03 & Reliability & $0.23 * *$ & $0.22 *$ & 0.19 \\
\hline IVRS support by Robots & $0.29 * * *$ & 0.07 & 0.09 & Empathy & $0.12 *$ & -0.02 & 0.16 \\
\hline $\begin{array}{c}\text { VR travel and } \\
\text { sightseeing experience } \\
\text { enhancement }\end{array}$ & $0.24^{* *}$ & 0.04 & 0.2 & Assurance & $0.53^{* * *}$ & $0.24 *$ & 0.08 \\
\hline $\begin{array}{l}\text { Auto Data management } \\
\text { Robots with AR. }\end{array}$ & -0.05 & 0.2 & -0.04 & & & & \\
\hline$R^{2}$ & 0.20 & 0.15 & 0.05 & $R^{2}$ & 0.65 & 0.17 & 0.23 \\
\hline
\end{tabular}

For testing hypotheses five and six, both web devices and physical employee service quality were subject to regression. We observed that the impact of Web 4.0 and 5.0 device service quality was negative when evaluating service quality. In contrast, physical employee service quality held strongly in this category. We also observed that other than empathy shown by physical employee service quality, none of the dimensions significantly affected tourist loyalty, as shown in Table 7 . Hence, this supports hypotheses 5 and 6 .

Table 7. Effect of Web 4.0 and 5.0 devices and physical employee service quality on overall service quality and tourist loyalty.

\begin{tabular}{ccc}
\hline Overall Service Quality & Service Quality & Tourist Loyalty \\
\hline & Web $\mathbf{4 . 0}$ and $\mathbf{5 . 0}$ device Service Quality & \\
\hline Social Robots & 0.07 & 0.14 \\
Digitalized support by Chatbots & -0.07 & -0.01 \\
IVRS support by Robots & 0.06 & -0.07 \\
VR travel and sight-seeing & 0.04 & -0.06 \\
experience enhancement & $-0.13^{*}$ & -0.08 \\
Auto Data management by Robots & & \\
with AR. & Physical Employee Service Quality & 0.3 \\
\hline & -0.03 & 0.16 \\
\hline Responsiveness & $0.24^{* *}$ & $0.18^{*}$ \\
Reliability & $0.13^{*}$ & 0.13 \\
Empathy & $0.56^{* * *}$ & 0.2 \\
Assurance & 0.65 &
\end{tabular}

\subsection{Findings}

Our findings indicate that tourists prefer to interact with social robots, finding them relatable, human-like, empathy-possessing, and a strong capacity to process information, which is still not available with other web technologies [57]. Web 4.0 devices like social robots are accepted by tourists, but Web 5.0 devices have evolved. Tourists were not able to differentiate VR and AR devices, nor their use as social robots; maybe they assumed that AR and VR devices were extensions of these robotic technologies. Once empathetic and information processing abilities are integrated into Web 5.0 devices, we are sure that they will have more acceptance than any other service quality possibility. IVRS and chatbots are becoming quite common and tourists' level of curiosity and use is not entirely exhibited. Thus, they need innovations and more differentiation.

Among physical employee service dimensions, reliability and assurance were found to strongly relate to tourist satisfaction, whereas responsiveness and empathy had an insignificant effect. This proves that tourists depend on physical service. The credibility and trustworthiness of employees is paramount for tourist satisfaction. Assurance and reliability represent the overall service quality for different services in the tourism ecosystem. Like most big hotels, they must provide inhouse services like a spa, masseuse, pub, bar, and sightseeing activities. With regard to empathetic services, we found 
that tourists were in favor of web devices, as such devices are programmed to offer standardized tools, where information can be processed more accurately than humans [7]. We found that tourists were mostly in favor of digitalized services because they did not want to interact with employees more than they had to. Surprisingly, no dimension had a direct effect on tourist loyalty, which was antagonistic in previous research [63]. Therefore, we believe that physical employee service can only attract long-term patronage, as machines cannot satisfy this hospitality goal. Each service encounter has to be accountable for tourist responses so that they can enhance service quality and tourist satisfaction.

\section{Discussions}

This research discusses the role of Web 4.0 and 5.0 devices for commercial sustainability in Ho Chi Minh City (HCMC), Vietnam's tourist ecosystem. The aim of this study was to commercially examine the viability of Web 4.0 and 5.0 devices for the tourist use. Further, we aimed to determine how much these devices could generate satisfaction and loyalty in the minds of tourists, especially when compared to physical services. These are duly discussed in Tables 6 and 7, and Figures 1 and 2.

This study focused on a pilot project that implemented Web 4.0 and 5.0 devices in the HCMS tourist ecosystem. Both military and adventure tourism were targeted. With AR and VR goggles, leisure tourism can be developed. Due to COVID-19, using these machines are fruitful for the tourism industry. In the wake of restrictions on employee services, these tools proved highly beneficial for the tourist ecosystem. With VR and AR, tourists can experience a place before visiting. In Japan, they have made dummy flights using goggles for a virtual experience. In Vietnam, the tourism industry can plan to provide a virtual trip where travel is otherwise not possible because of COVID-19 restrictions. In Vietnam, cave tourism is also prevalent, but caves are difficult to access during the rainy season. However, these places and their experience can be promoted through virtual augmented devices. If establishments like hotels and spas know what tools to appropriately use with tourists, they will save money. In spas, the human element may not be used even when COVID-19 restrictions are lifted, but social robots can be used to resume service. This will create interest, despite the lack of the human element.

\section{Future Scope}

The key operationalized elements of satisfaction and loyalty coexist in tourists' minds. Therefore, we are curious how to best incorporate the physical aspect of service. To do so, we need to conduct difficult research to examine the perceptual and neurological dimensions of tourists. We hope this study adds insights to such a necessary research conversation. This study is unique in the sense it considers both AI and VR. We did not differentiate between devices, but nonetheless explored the service quality of these devices and empirically compared them to physical service. From a tourist's perspective, these devices represent a nascent use of new technologies, which may prefigure future technologies, especially in the wake of COVID-19. Indeed, visitors are both curious and anxious to use these devices. Our findings suggest that physical employees must find specific roles beyond standardized service because Web 4.0 and 5.0 devices are better at accomplishing these services. Yet machines cannot replace human beings in the tourist ecosystem until techno-loyalty and fully techno-empathy practically occur.

\section{Conclusions}

This research examines how Web 4.0 and 5.0 devices impact service quality and tourist loyalty compared to physical employee service in HCMC's tourist ecosystem. Our findings indicate VR and AR innovations in this tourist ecosystem. Web 4.0 devices like social robots benefits tourist satisfaction. Hopefully, with their empathetic activities and information processing, promptness can win tourists' loyalty in the long run. Although machines cannot replace humans, they can undoubtedly be assets in areas where humans may lack. Furthermore, they can support various establishments where human behavior may not give appreciable satisfaction and long-term patronage. We also considered the opinions of senior employees. Since different establishments spend a lot of money to deploy 
these devices, they hope that the usage of these devices improves tourist satisfaction and loyalty. Otherwise, they may incur unnecessary expenses which will have less return.

This study is suitable to improve the service quality of various tourist. These techno-human combined aspects can help better position and develop a unique platform in this ASEAN region. Tourist loyalty and satisfaction may showcase HCMC as a tech-driven destination in the world's future tourism map. Some experts have raised the issue of job loss and lack of human involvement. We can only conclude that this aspect needs to be better researched after the deployment of these devices and applications. Not addressing this future research topic is a limitation of the present study [69-71]. We also did not consider tourists with no previous Web 4.0 or 5.0 device experience. People without such experiences could offer a substantial contribution to the future scholarly conversation [72,73]. In the wake of COVID-19, these devices can help revive the tourism and hospitality sectors, such as wellness tourism, military tourism, and cave tourism. For as long as physical employee services are not restored, establishments can use devices to attract tourists. Web 4.0 and 5.0 applications enhance one's technological experience If managed properly, they can give a boost to one's leisure experience.

In this study, we assisted non-academic experts like senior employees to prepare a questionnaire, which may be one of our study's limitations. Because this study is based in Vietnam, we did not consider other countries. In Vietnam, luxury hotels provide most accessory services to tourists. Thus, future research might examine a luxury hotel with more specialized Web 4.0 and 5.0 devices.

Author Contributions: Conceptualization, N.T.D.; methodology, S.R.M.; software, S.D.; validation, N.T.T.V., D.X.H.M. and S.R.M.; formal analysis, S.D.; investigation, P.T.D.; resources, N.T.D.; data curation, S.D.; writing original draft, S.D.; writing—review and editing, S.D.; visualization, S.D.; supervision, N.T.D. All authors have read and agreed to the published version of the manuscript.

Funding: This research is funded by Ho Chi Minh City's Department of Science and Technology (HCMC-DOST) and the Institute for Computational Science and Technology (ICST) under the project: Research the Impact of Artificial Intelligence (Ai) On Using Tourism Products And Services In Ho Chi Minh City: Application Of Research On Consumer Behavior Through The Impact Of Technology: Funding grant contract number: 33/2020/HĐ-QPTKHCN; dated 6th July 2020.

Acknowledgments: We acknowledge all the tourists who have given responses through the survey.

Conflicts of Interest: The authors declare no conflict of interest.

\section{Appendix A}

Table A1. Questionnaire items given to tourists.

\begin{tabular}{cc}
\hline & Questionnaire Main Items \\
\hline & Social Robots \\
\hline Item 1 & $\begin{array}{r}\text { You follow and like the suggestions of sightseeing from social robots } \\
\text { You feel happy when the robot responds to your queries } \\
\text { You like the games the robots plays or suggests while you wait }\end{array}$ \\
\hline Digitalized support by Chatbots \\
\hline Item 4 & You are happy to have a prompt access to service \\
Item 5 & $\begin{array}{r}\text { You do not have to wait for any online query with Chatbots } \\
\text { You like the itinerary scheduling done by Chatbots }\end{array}$ \\
\hline Item 6 & IVRS support by Robots \\
\hline Item 7 & You like to order food using IVRS support \\
Item 8 & You like the robot's advice on the special menu \\
Item 9 & You prefer the IVRS of robots to assist in regulating temperature and room lighting \\
\hline Item 10 & VR travel and sightseeing experience enhancement \\
Item 11 & You like the attractive places and know it better through VR devices \\
Item 12 & $\begin{array}{r}\text { You prefer the virtual promotional offers and advertisements in VR } \\
\text { You feel good using VR for booking and experiencing routes }\end{array}$ \\
\hline & Auto Data management; Robots with AR \\
\hline Item 13 & You prefer customized offers given by data management devices with AR \\
Item 14 & You like how AR remembers your preferences and website browsing history \\
Item 15 & You appreciate the return journey assistance given by the devices \\
\hline
\end{tabular}




\section{References}

1. Gursoy, D.; Chi, O.H.; Lu, L.; Nunkoo, R. Consumers' acceptance of artificially intelligent (AI) device use in service delivery. Int. J. Inf. Manag. 2019, 49, 157-169. [CrossRef]

2. Chi, O.H.; Denton, G.; Gursoy, D. Artificially intelligent device use in service delivery: A systematic review, synthesis, and research agenda. J. Hosp. Mark. Manag. 2020, 1-30. [CrossRef]

3. Lin, H.; Chi, O.H.; Gursoy, D. Antecedents of customers' acceptance of artificially intelligent robotic device use in hospitality services. J. Hosp. Mark. Manag. 2019, 29, 530-549. [CrossRef]

4. Lu, L.; Cai, R.; Gursoy, D. Developing and validating a service robot integration willingness scale. Int. J. Hosp. Manag. 2019, 80, 36-51. [CrossRef]

5. Parasuraman, A.; Zeithaml, V.A.; Berry, L.L. The behavioral consequences of service quality. J. Mark. 1996, 60, 31-46.

6. Bowen, J.; Morosan, C. Beware hospitality industry: The robots are coming. Worldw. Hosp. Tour. Themes 2018, 10, 726-733. [CrossRef]

7. Ivanov, S.; Webster, C. Robots, Artificial Intelligence and Service Automation in Travel, Tourism and Hospitality; Ivanov, S., Webster, C., Eds.; Emerald Publishing Limited: Bingley, UK, 2019.

8. Naumov, N. The Impact of Robots, Artificial Intelligence, and Service Automation on Service Quality and Service Experience in Hospitality. In Robots, Artificial Intelligence, and Service Automation in Travel, Tourism, and Hospitality; Emerald Publishing Limited: Bingley, UK, 2019; pp. 123-133.

9. Fuchs, C.; Hofkirchner, W.; Schafranek, M.; Raffl, C.; Sandoval, M.; Bichler, R. Theoretical foundations of the web: Cognition, communication, and co-operation. Towards an understanding of Web 1.0, 2.0, 3.0. Future Internet 2010, 2, 41-59. [CrossRef]

10. Davis, M. Semantic Wave 2008 Report: Industry Roadmap to Web 3.0 and Multibillion-Dollar Market Opportunities; Davis, M., Ed.; Project 10X: Washington, DC, USA, 2008.

11. Patel, K. Incremental journey for the World Wide Web: Introduced with Web 1.0 to recent Web 5.0-A survey paper. Int. J. Adv. Res. Comput. Sci. Softw. Eng. 2013, 3, 410-417.

12. Virtual Reality in Tourism Blog. Available online: http://www.virtual-reality-in-tourism.com/ (accessed on 17 July 2020).

13. Beck, J. VR Time Travel: Step into Old Hong Kong. Available online: http://www.virtual-reality-in-tourism. com/vr-time-travel-hong-kong/ (accessed on 11 July 2020).

14. Egger, R. Creating Unique Experiences with Virtual Reality. Available online: http://www.virtual-reality-intourism.com/creating-unique-experiences-virtual-reality/ (accessed on 17 July 2020).

15. Beck, J. How will Technological Developments Influence VR Travel? Available online: www.virtual-realityin-tourism.com/influence-technological-developments/ (accessed on 10 July 2020).

16. Aghayev, R. VR-The Future of Selling Hotel Rooms. Available online: http://www.virtual-reality-in-tourism. com/vr-future-selling-hotel-rooms/ (accessed on 8 July 2020).

17. Lai, K.; Li, X. Tourism destination image: Conceptual problems and definitional solutions. J. Travel Res. 2016, 55, 1065-1080. [CrossRef]

18. Hager, J.; Mayrhofer, T. Virtual Reality and Destination Image Formation. In ISCONTOUR 2018 Tourism Research Perspectives: Proceedings of the International Student Conference in Tourism Research; BoD-Books on Demand: Norderstedt, Germany, 2018.

19. McFee, A.; Mayrhofer, T.; Baràtovà, A.; Neuhofer, B.; Rainoldi, M.; Egger, R. The effects of virtual reality on destination image formation. In Information and Communication Technologies in Tourism 2019; Springer: Cham, Switzerland, 2019; pp. 107-119.

20. Mayrhofer, T. VR and Destination Image Formation. Available online: http://www.virtual-reality-in-tourism. com/vr-destination-image-formation/ (accessed on 10 July 2020).

21. Rogers, S. How Virtual Reality Could Help the Travel and Tourism Industry in the Aftermath of the Coronavirus Outbreak? Available online: https://www.forbes.com/sites/solrogers/2020/03/18/virtual-realityand-tourism-whats-already-happening-is-it-the-future/\#28fdc26f28a6 (accessed on 12 June 2020).

22. McKendrick, J. Artificial Intelligence Will Replace Tasks, Not Jobs. Forbes. Available online: https://www. forbes.com/sites/joemckendrick/2018/08/14/artificial-intelligence-will-replace-tasks-not-jobs/\#89f21c8a7fa4 (accessed on 12 June 2020). 
23. Wirtz, J.; Patterson, P.G.; Kunz, W.H.; Gruber, T.; Lu, V.N.; Paluch, S.; Martins, A. Brave new world: Service robots in the frontline. J. Serv. Manag. 2018, 46, 59-80. [CrossRef]

24. Vietnam Aims to Lure 18 Million Foreign Tourists in 2019. Available online: https://english.vietnamnet.vn/ fms/travel/214900/vietnam-aims-to-lure-18-million-foreign-tourists-in-2019.html (accessed on 10 June 2020).

25. Tourism in Vietnam Wikipedia. Available online: https://en.wikipedia.org/wiki/Tourism_in_Vietnam (accessed on 10 June 2020).

26. Popular Destinations-Asia. Available online: https://www.tripadvisor.com/TravelersChoice-Destinationsg2 (accessed on 10 June 2020).

27. Elliott, C. Chatbots Are Killing Customer Service. Here's Why. Available online: https://www.forbes.com/sites/ christopherelliott/2018/08/27/chatbots-are-killing-customer-service-heres-why/\#3e8179eb13c5 (accessed on 12 June 2020).

28. Cronin, J.J., Jr.; Taylor, S.A. SERVPERF versus SERVQUAL: Reconciling performance-based and perceptions-minus-expectations measurement of service quality. J. Mark. 1994, 58, 125-131. [CrossRef]

29. Kaplan, A.; Haenlein, M. Siri, Siri, in my hand: Who's the fairest in the land? On the interpretations, illustrations, and implications of artificial intelligence. Bus. Horiz. 2019, 62, 15-25. [CrossRef]

30. Russell, S.; Norvig, P. Artificial Intelligence: A modern Approach; Prentice-Hall: New Jersey, NJ, USA, 2002.

31. Bolton, C.; Machová, V.; Kovacova, M.; Valaskova, K. The power of human-machine collaboration: Artificial intelligence, business automation, and the smart economy. Econ. Manag. Financ. Mark. 2018, 13, 51-56.

32. Chung, M.; Ko, E.; Joung, H.; Kim, S.J. Chatbot e-service and customer satisfaction regarding luxury brands. J. Bus. Res. 2018, 117, 587-595. [CrossRef]

33. Van Belleghem, S. Customers the Day after Tomorrow: How to Attract Customers in a World of AI, Bots, and Automation; Lannoo Meulenhoff: Tielt, Belgium, 2017.

34. Solomon, M. Technology Invades the Hospitality Industry: Hilton Robot, Domino Delivery Droid, Ritz-Carlton Mystique. Available online: https:/www.forbes.com/sites/micahsolomon/2016/03/18/hightech-hospitality-hilton-robot-concierge-dominos-delivery-droid-ritz-carlton-mystique/\#47257f35120b (accessed on 18 June 2020).

35. Kuo, C.M.; Chen, L.C.; Tseng, C.Y. Investigating an innovative service with hospitality robots. Int. J. Contemp. Hosp. Manag. 2017, 29, 1305-1321. [CrossRef]

36. Humanoid Clerk Helps to Cut Red Tape in Russia. Available online: https://in.reuters.com/article/russiatechnology-robot-idINKCN24F0OW (accessed on 16 July 2020).

37. Moon, M. Spot and Pepper Robots Will Perform at Spectator Less Baseball Games in Japan. Available online: https://www.engadget.com/spot-pepper-robot-spectatorless-baseball-games-japan-101535505.html (accessed on 16 July 2020).

38. Robots Built for Japan's Aging Workforce Finds Corona Virus Role. Available online: https://in.reuters. com/article/us-health-coronavirus-japan-robot/robot-built-for-japans-aging-workforce-finds-coronavirusrole-idINKBN23G190?utm_campaign=fullarticleandutm_medium=referralandutm_source=inshorts (accessed on 16 July 2020).

39. A Robot Walks Into a Bar, Helps Make a Cocktail. Available online: https://in.reuters.com/article/healthcoronavirus-southkorea-robot-bart/a-robot-walks-into-a-bar-helps-make-a-cocktail-idINKBN23B0RK (accessed on 16 July 2020).

40. Piçarra, N.; Giger, J.C. Predicting intention to work with social robots at the anticipation stage: Assessing the role of behavioral desire and anticipated emotions. Comput. Hum. Behav. 2018, 86, 129-146. [CrossRef]

41. Li, J.J.; Bonn, M.A.; Ye, B.H. Hotel employee's artificial intelligence and robotics awareness and its impact on turnover intention: The moderating roles of perceived organizational support and competitive psychological climate. Tour. Manag. 2019, 73, 172-181. [CrossRef]

42. Neuburger, L.; Beck, J.; Egger, R. The 'Phygital' Tourist Experience: The Use of Augmented and Virtual Reality in Destination Marketing. In Tourism Planning and Destination Marketing; Emerald Publishing Limited: Bingley, UK, 2018.

43. Tussyadiah, I.P.; Wang, D.; Jung, T.H.; Tom Dieck, M.C. Virtual reality, presence, and attitude change: Empirical evidence from tourism. Tour. Manag. 2018, 66, 140-154. [CrossRef]

44. Huang, Y.C.; Backman, K.F.; Backman, S.J.; Chang, L.L. Exploring the implications of virtual reality technology in tourism marketing: An integrated research framework. Int. J. Tour. Res. 2016, 18, 116-128. [CrossRef] 
45. Tussyadiah, I.P.; Wang, D.; Jia, C.H. Virtual Reality and Attitudes toward Tourism Destinations. In Information and Communication Technologies in Tourism 2017; Springer: Cham, Switzerland, 2017; pp. 229-239.

46. Guttentag, D.A. Virtual reality: Applications and implications for tourism. Tour. Manag. 2010, 31, 637-651. [CrossRef]

47. Meuter, M.L.; Ostrom, A.L.; Roundtree, R.I.; Bitner, M.J. Self-service technologies: Understanding customer satisfaction with technology-based service encounters. J. Mark. 2000, 64, 50-64. [CrossRef]

48. Kumar, V. A customer lifetime value-based approach to marketing in the multichannel, multimedia retailing environment. J. Interact. Mark. 2010, 24, 71-85. [CrossRef]

49. Mithas, S.; Krishnan, M.S.; Fornell, C. Why do customer relationship management applications affect customer satisfaction? J. Mark. 2005, 69, 201-209. [CrossRef]

50. McKecnie, S.; Ganguli, S.; Roy, S.K. Generic technology-based service quality dimensions in banking. Int. J. Bank Mark. 2011, 29, 168-189.

51. Delcourt, C.; Gremler, D.D.; Van Riel, A.C.; Van Birgelen, M. Effects of perceived employee emotional competence on customer satisfaction and loyalty. J. Serv. Manag. 2013, 24, 5-24. [CrossRef]

52. Heskett, J.L.; Jones, T.O.; Loveman, G.W.; Sasser, W.E.; Schlesinger, L.A. Putting the service-profit chain to work. Harv. Bus. Rev. 1994, 72, 164-174.

53. Yung, R.; Khoo-Lattimore, C. New realities: A systematic literature review on virtual reality and augmented reality in tourism research. Curr. Issues Tour. 2019, 22, 2056-2081. [CrossRef]

54. Bogicevic, V.; Seo, S.; Kandampully, J.A.; Liu, S.Q.; Rudd, N.A. Virtual reality presence as a preamble of tourism experience: The role of mental imagery. Tour. Manag. 2019, 74, 55-64. [CrossRef]

55. Loureiro, S.R.M.C.; Guerreiro, J.; Ali, F. 20 years of research on virtual reality and augmented reality in tourism context: A text-mining approach. Tour. Manag. 2020, 77, 104028. [CrossRef]

56. Kim, M.J.; Lee, C.K.; Jung, T. Exploring consumer behavior in virtual reality tourism using an extended stimulus-organism-response model. J. Travel Res. 2020, 59, 69-89. [CrossRef]

57. Murphy, J.; Gretzel, U.; Pesonen, J. Marketing robot services in hospitality and tourism: The role of anthropomorphism. J. Travel Tour. Mark. 2019, 36, 784-795. [CrossRef]

58. Sentence, R. Robots or Humans: Which Provides a Better Customer Experience. 2018. Available online: https://econsultancy.com/robots-or-humans-which-provide-a-better-customer-experience/ (accessed on 17 July 2020).

59. Glaser, A. When Robots Make Us Angry, Humans Pay the Price. 2017. Available online: https://slate.com/business/2017/09/customers-who-get-angry-at-robots-take-out-their-frustrationsonhuman-employees.html (accessed on 17 July 2020).

60. How Cutting-Edge Hotels Use Artificial Intelligence for a Great Guest Experience. Available online: https: //www.phocuswire.com/How-cutting-edge-hotelsuse-artificial-intelligence-for-a-great-guest-experience (accessed on 17 July 2020).

61. Bogicevic, V.; Bujisic, M.; Bilgihan, A.; Yang, W.; Cobanoglu, C. The impact of traveler-focused airport technology on traveler satisfaction. Technol. Forecast. Soc. Chang. 2017, 123, 351-361. [CrossRef]

62. Cronin, J.J., Jr.; Brady, M.K.; Hult, G.T.M. Assessing the effects of quality, value, and customer satisfaction on consumer behavioral intentions in service environments. J. Retail. 2000, 76, 193-218. [CrossRef]

63. Kandampully, J.; Suhartanto, D. The role of customer satisfaction and image in gaining customer loyalty in the hotel industry. J. Hosp. Leis. Mark. 2003, 10, 3-25. [CrossRef]

64. Tabachnick, B.G.; Fidell, L.S.; Ullman, J.B. Using Multivariate Statistics; Pearson: Boston, MA, USA, 2007; Volume 5, pp. 481-498.

65. Brickman Bhutta, C. Not by the book: Facebook as a sampling frame. Sociol. Methods Res. 2012, 41, 57-88. [CrossRef]

66. Podsakoff, P.M.; MacKenzie, S.B.; Lee, J.Y.; Podsakoff, N.P. Common method biases in behavioral research: A critical review of the literature and recommended remedies. J. Appl. Psychol. 2003, 88, 879. [CrossRef]

67. Blau, G.; Chapman, S.; Pred, R.S.; Lopez, A. Can a four-dimensional model of occupational commitment help to explain intent to leave the emergency medical service occupation? J. Allied Health 2009, 38, 177-186.

68. Jayachandran, S.; Sharma, S.; Kaufman, P.; Raman, P. The role of relational information processes and technology use in customer relationship management. J. Mark. 2005, 69, 177-192. [CrossRef]

69. Singh, S.; Mondal, S.; Singh, L.B.; Sahoo, K.K.; Das, S. An Empirical Evidence Study of Consumer Perception and Socioeconomic Profiles for Digital Stores in Vietnam. Sustainability 2020, 12, 1716. [CrossRef] 
70. Mohanty, P.C.; Dash, M.; Dash, M.; Das, S. A study on factors influencing training effectiveness. Rev. Espac. 2019, 40,7-15.

71. Singh, S.; Das, S. Impact of post-merger and acquisition activities on the financial performance of banks: A study of the Indian private sector and public sector banks. Rev. Espac. Mag. 2018, 39, 25.

72. Mondal, S.; Mall, M.; Mishra, U.S.; Sahoo, K. Investigating the factors affecting customer purchase activity in retail stores. Rev. Espac. 2017, 38, 22-44.

73. Mondal, S.; Das, S.; Musunuru, K.; Dash, M. Study on the factors affecting customer purchase activity in retail stores by confirmatory factor analysis. Rev. Espac. 2017, 38, 30-54.

(C) 2020 by the authors. Licensee MDPI, Basel, Switzerland. This article is an open access article distributed under the terms and conditions of the Creative Commons Attribution (CC BY) license (http://creativecommons.org/licenses/by/4.0/). 